\title{
Analysis of the gene expression profile of mouse male meiotic germ cells
}

\author{
Pellegrino Rossi ${ }^{\mathrm{a}, *, 1}$, Susanna Dolci ${ }^{\mathrm{a}, 1}$, Claudio Sette ${ }^{\mathrm{a}, 1}$, Federica Capolunghi ${ }^{\mathrm{a}}$, \\ Manuela Pellegrini $^{a}$, Maria Loiarro ${ }^{a}$, Silvia Di Agostino ${ }^{a}$, Maria Paola Paronetto ${ }^{a}$, \\ Paola Grimaldi ${ }^{\mathrm{a}}$, Daniele Merico ${ }^{\mathrm{b}}$, Enzo Martegani ${ }^{\mathrm{b}}$, Raffaele Geremia ${ }^{\mathrm{a}}$ \\ a'Dipartimento di Sanita' Pubblica e Biologia Cellulare, Sezione di Anatomia, Universita' di Roma Tor Vergata, Via Montpellier 1, 00133 Rome, Italy \\ 'Dipartimento di Biotecnologie e Bioscienze, Universita' di Milano Bicocca, Piazza della Scienza 2, 20126 Milan, Italy
}

Received 31 October 2003; received in revised form 7 November 2003; accepted 18 November 2003

\begin{abstract}
Wide genome analysis of difference in gene expression between spermatogonial populations from 7-day-old mice and pachytene spermatocytes from 18-day-old mice was performed using Affymetrix gene chips representing 12,500 mouse known genes or EST sequences, spanning approximately $1 / 3 \mathrm{rd}$ of the mouse genome. To delineate differences in the profile of gene expression between mitotic and meiotic stages of male germ cell differentiation, expressed genes were grouped in functional clusters. The analysis confirmed the previously described pre-meiotic or meiotic expression for several genes, in particular for those involved in the regulation of the mitotic and meiotic cell cycle, and for those whose transcripts are accumulated during the meiotic stages to be translated later in post-meiotic stages. Differential expression of several additional genes was discovered. In few cases (pro-apoptotic factors Bak, Bad and Bax), data were in conflict with the previously published stage-dependent expression of genes already known to be expressed in male germ cells. Northern blot analysis of selected genes confirmed the results obtained with the microarray chips. Six of these were novel genes specifically expressed in pachytene spermatocytes: a chromatin remodeling factor (chracl/YCL1), a homeobox gene ( $h m x$ l), a novel G-coupled receptor for an unknown ligand (Gpr19), a glycoprotein of the intestinal epithelium (mucin 3), a novel RAS activator (Ranbp9), and the A630056B21Rik gene (predicted to encode a novel zinc finger protein). These studies will help to delineate the global patterns of gene expression characterizing male germ cell differentiation for a better understanding of regulation of spermatogenesis in mammals.

(C) 2003 Elsevier B.V. All rights reserved.
\end{abstract}

Keywords: DNA microarray; Transcriptome analysis; Spermatogenesis; Spermatocytes; Spermatogonia; Meiosis

\section{Results and discussion}

Spermatogenesis is characterized by a mitotic (spermatogonia), a meiotic (spermatocytes) and a differentiative haploid (spermatids) phase. The dissection of the mechanisms that regulate the mitotic and meiotic cell cycles in mammalian germ cells is useful for a better understanding of the molecular requirements for spermatogenesis to occur, and thus for the understanding of male sterility, which is often based on lack of spermatogonial divisions or meiotic blocks. Spermatogonia actively proliferate under the control of growth factors released by somatic cells of

\footnotetext{
Supplementary data associated with this article can be found, in the online version, at doi:10.1016/j.modgep.2003.11.003.

* Corresponding author. Tel.: +39-672596272; fax: +39-672596268.

E-mail address: pellegrino.rossi@med.uniroma2.it (P. Rossi).

${ }^{1}$ The first three authors contributed equally to this paper.
}

the seminiferous epithelium, such as Bone morphogenetic protein 4 (Bmp4), which stimulates the Alk3 receptor expressed in spermatogonial stem cells (Pellegrini et al., 2003), and Kit Ligand (also called Stem Cell Factor), which activates the c-kit receptor expressed in differentiating spermatogonia (Sorrentino et al., 1991; Yoshinaga et al., 1991; Rossi et al., 1993; Schrans-Stassen et al., 1999; Dolci et al., 2001).

Few informations are available on the control of the differentiation of spermatogonia into spermatocytes, i.e. their entrance into the meiotic cell cycle, which is characterized by two cell divisions and genetic exchange (crossing-over) between homologous chromosomes, and produce four haploid spermatids from each diploid progenitor cell (Roeder, 1997). Insights into the molecular mechanisms of the progression to the metaphase of the first meiotic division have been obtained by treatment of 
cultured spermatocytes with okadaic acid (OA), which overcomes normal checkpoints that ensure in vivo the slow progression of the meiotic prophase. OA triggers the sequential activation of ERK1, p90Rsk2 and Nek2, thus leading to chromosome condensation and progression to metaphase with the concurrent activation of the cyclin B/cdk1 complex (Sette et al., 1999; Di Agostino et al., 2002). The spermatids that result at the end of meiosis will then undergo spermiogenesis with the final production of mature spermatozoa. The aim of our work was to obtain a general profile of the expression pattern of genes specifically involved in the transition from the mitotic to the meiotic cell cycle and in the progression through the meiotic cell cycle.

DNA microarrays can be used to measure the expression patterns of thousands of genes in parallel, allowing to monitor changes in gene expression occurring during developmental events (Schena, 1996). Analysis of the results obtained with the microarray technique allows the clustering of expressed genes in functional classes. We used this approach in order to identify genes specifically involved in the meiotic program and to group these genes in clusters that should give more informations about the molecular interactions required for this peculiar type of cell cycle in mammals.

We prepared complementary RNAs from two germ cell types at different developmental stages purified from testes of pre-puberal mice, spermatogonia from 7-day-old mice and spermatocytes from 18-day-old mice. The spermatogonial population obtained from 7-day-old mice (type A and B spermatogonia) is contaminated by $10 \%$ of somatic cells, whereas germ cells in the meiotic prophase are absent (Dolci et al., 2001; Pellegrini et al., 2003; see also Section 2). Spermatocytes obtained after elutriation from 18-day-old mice are in the middle-late pachytene stage of the first meiotic prophase $(85 \%)$ and in the leptotene-zygotene stage (10\%). Contamination of spermatogonia and somatic cells in the meiotic cell population is less than $5 \%$, whereas round spermatids, which are a common contaminant of pachytene fractions when using adult testis (Sette et al., 1999; Di Agostino et al., 2002), are absent, not being present in the immature testis used. The cRNAs prepared from the two different cell populations have been hybridized with commercially available MG-U74Av2 GeneChip probe arrays (Affymetrix Inc.), containing $\sim 12,500$ known mouse genes or EST sequences, and thus spanning approximately $1 / 3 \mathrm{rd}$ of the mouse genome. The analysis was performed on duplicate chip arrays, using cRNAs from two different cell preparations. The results of array data and the comparative analysis were very similar in the duplicate experiments (Fig. 1) and are available in the supplemental data. The same data are also available online at the addresses http://www2.uniroma2.it/ricerca/ce/ absolutevaluestot.htm and http://www2.uniroma2.it/ ricerca/ce/comparativeanalysistot.htm. The files named 'Absolute Values' contain filtered raw data of the absolute analysis. Each of the five files contains data relative to $\sim 1 / 5$ th of the targets represented in the Affymetrix MG-U74Av2 array. In the first column, the Affymetrix identification number of the target oligonucleotide probe pairs is indicated. Signal is a numeric value measuring the abundance of a transcript revealed by the duplicate arrays (C1 and C2: spermatocytes; G1 and G2: spermatogonia). Detection indicates whether a transcript is present $(\mathrm{P})$, marginal (M), or absent (A) according to statistical analysis. Detection $P$-value indicates the significance level of detection call (P: $P$-value $<0.04 ; \mathrm{M}: P$-value between 0.04 and 0.06; A: $P$-value $>0.06$ ). Descriptions contain the Affymetrix informations about the target gene. More informations about the target genes (especially those corresponding to EST sequences) can be found with the Interacting Query online facility at www.affymetrix.com. The files named: 'Comparative Analysis' contain comparison data between paired samples of spermatocytes $(\mathrm{C} 2-\mathrm{C} 1)$, spermatogonia $(\mathrm{G} 2-\mathrm{G} 1)$, and between the two different cell populations in the duplicate arrays $(\mathrm{G} 1-\mathrm{C} 1$ and $\mathrm{G} 2-\mathrm{C} 2$ ). Signal $\log$ ratio indicates the change expression level for a transcript between the compared samples, and corresponds to the base 2 logarithm of the fold difference (for instance, a signal $\log$ ratio of 3 , or of -3 , indicates that the transcript corresponding to the target gene is 8-fold more abundant in the first or the second, respectively, of the two compared samples). Signal log ratio low/high represent the lower and upper limit of signal $\log$ ratio within a $95 \%$ of confidence interval. Change indicates whether the target gene expression is increased (I), marginally increased (MI), not changed (NC), marginally decreased (MD) or decreased (D) in the first vs. the second sample according to statistical analysis. Change in $P$-value indicates the significance level of change call (I: $P$-value $<0.0025$; MI: $P$-value between 0.0025 and 0.003; NC: $P$-value between 0.003 and 0.997 ; MD: $P$-value between 0.0997 and 0.9975 ; D: $P$-value $>0.9975$ ).

A positive signal (detection parameter: $P$ in both samples) for $\sim 3500$ target sequences was obtained in spermatocytes, vs. $\sim 5500$ in spermatogonia. Comparative analysis identified $\sim 2000$ target sequences with a signal significantly higher in spermatogonia (change parameter: I in both samples), and $\sim 700$ target sequences with a signal significantly higher in spermatocytes (change parameter: D in both samples).

Between most of the targets that gave a higher signal in spermatogonia, the selective expression in this cell population was already known from published data. A limited and representative list of such genes is shown in Table 1. We ordered these genes according to the average Signal Log Ratio parameter, which was converted in average fold difference of the signal in spermatogonia vs. spermatocytes. We also considered whether the target, besides giving a higher signal in spermatogonia, gave a positive (detection parameter: $\mathrm{P}$ ) or negative (detection parameter: A) signal in spermatocytes. The calculation 

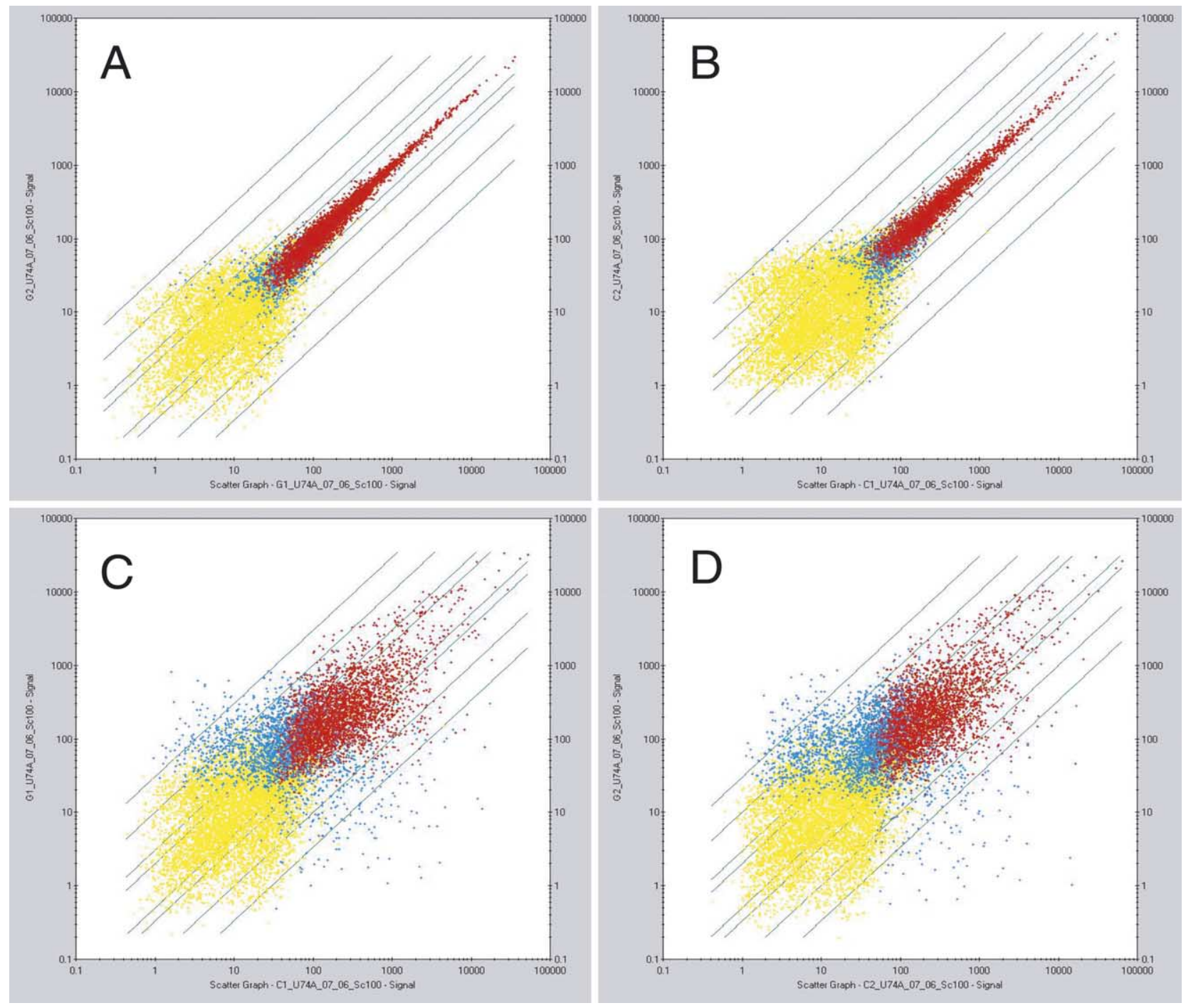

Fig. 1. Analysis of the homogeneity of microarray generated signals between duplicate samples of spermatogonia and spermatocyte cRNA probes, and comparative analysis of the divergence between spermatogonia and spermatocytes. Data represent scatter plots of (A) spermatogonia sample 1 intensities (G1) vs. spermatogonia sample 2 intensities (G2); (B) spermatocytes sample 1 (C1) vs. spermatocytes sample 2 (C2); (C) spermatogonia sample 1 (G1) vs. spermatocytes sample 1 (C1); (D) spermatogonia sample 2 (G2) vs. spermatocytes sample 2 (C2). In these scatter plots, each spot corresponds to the signal generated by a discrete Affymetrix target gene, each represented on the chip arrays by 16 specific 25 mer oligonucleotide probes and by 16 one-mismatch probes. In A and in B the data fit a straight line with slope approximately equal to one and intercept near zero, demonstrating high reproducibility of the results. In $\mathrm{C}$ and $\mathrm{D}$, the enlargement of spot distribution is very similar in both comparative analysis, and allows to define statistically significant difference in selective gene expression between the two cell populations. Red dots represent genes significantly expressed in both samples $(P$-value $<0.04)$. Blue dots genes expressed significantly only in one sample, and yellow dots genes not expressed $(P$-value $>0.06)$ in both samples. The $P$-values are calculated as described in the Statistical Algorithms Reference Guide by Affymetrix (see Section 2).

of the fold difference of the signal between the two cell populations does not take into account whether the target gene is significantly expressed or not in spermatocytes. It should be noticed that we found no X-linked genes whose expression was higher in spermatocytes with respect to spermatogonia, in agreement with the notion of the inactivation of the $\mathrm{X}$ chromosome during the first meiotic prophase (Kelly, 1987). The Ott (ovary-testis transcribed) gene, a member of a mouse X-linked multigene family, was found to be expressed at very high levels in spermatogonia, whereas no significant expression was detected in spermatocytes, even though, on the basis of the observation that it was not expressed in the testes of adult sex-reversed mice lacking germ cells, it was previously reported to be expressed specifically during meiosis (Kerr et al., 1996). Thus, it appears that this gene might play a role, if any, only in the pre-meiotic stages of differentiation. On the other hand, we confirmed the specific and strong pre-meiotic expression of Stra8 (stimulated by retinoic acid gene 8) (Oulad-Abdelghani et al., 1996), and of Atm (ataxia 
Table 1

Examples of genes selectively expressed in spermatogonia

\begin{tabular}{|c|c|c|c|c|}
\hline $\begin{array}{l}\text { MG-U74Av2 } \\
\text { target } \\
\text { Affymetrix }\end{array}$ & Gene name & Gene symbol & Notes & $\begin{array}{l}\text { Fold difference } \\
\text { (spermatogonia } \\
\text { vs. spermatocytes) }\end{array}$ \\
\hline 92306 & Ovary-testis transcribed & Ott & $\begin{array}{l}\text { Absent in spermatocytes. X-linked gene, previously } \\
\text { defined as 'meiosis specific' (Kerr et al., 1996) }\end{array}$ & 104 \\
\hline 101194 & Stimulated by retinoic acid gene 8 & Stra8 & $\begin{array}{l}\text { Absent in spermatocytes. Pre-meiotic germ cell-specific } \\
\text { cytoplasmic protein encoded by Stra8, a retinoic acid- } \\
\text { responsive gene (Oulad-Abdelghani et al., 1996) }\end{array}$ & 50 \\
\hline 101180 & $\begin{array}{l}\text { Ataxia telangiectasia mutated } \\
\text { homolog }\end{array}$ & Atm & $\begin{array}{l}\text { Absent in spermatocytes. Protein kinase involved in } \\
\text { DNA repair and DNA damage response (induction of } \\
\text { apoptosis by DNA damage). In knock-out mice } \\
\text { gametogenesis is severely disrupted as early as } \\
\text { leptonema of prophase I (Barlow et al., 1998) }\end{array}$ & 15 \\
\hline 93536 & Bcl2-associated X protein & Bax & $\begin{array}{l}\text { Absent in spermatocytes. Pro-apoptotic factor (Yan } \\
\text { et al., 2000) }\end{array}$ & 9 \\
\hline 102963 & E2F transcription factor 1 & E2f1 & $\begin{array}{l}\text { Absent in spermatocytes. Transcription factor crucial for } \\
\text { mitotic cell cycle control (Dolci et al., 2001) }\end{array}$ & 6 \\
\hline 103207 & DNA polymerase $\alpha 1,180 \mathrm{kDa}$ & Pola1 & $\begin{array}{l}\text { Absent in spermatocytes. Dna replication (Orlando et al., } \\
1989 \text { ) }\end{array}$ & 6 \\
\hline 94448 & B-cell leukemia/lymphoma 10 & $\mathrm{Bcl} 10$ & Present in spermatocytes. Pro-apoptotic factor & 6 \\
\hline 160159 & Cyclin B1 & Ccnb1 & $\begin{array}{l}\text { Absent in spermatocytes. Subunit of cdc } 2 / \mathrm{cdk} 1 \text {, } \\
\text { essential for G2/M transition }\end{array}$ & 5 \\
\hline 103057 & $\begin{array}{l}\text { DNA polymerase } \delta 1 \text {, catalytic } \\
\text { domain }\end{array}$ & Pold1 & Absent in spermatocytes. Dna replication & 4 \\
\hline 92767 & $\begin{array}{l}\text { Bone morphogenetic protein } \\
\text { receptor, type } 1 \mathrm{~A}\end{array}$ & Bmpr1a, ALK3 & $\begin{array}{l}\text { Absent in spermatocytes. Bone morphogenetic receptor } \\
\text { for Bmp2 and Bmp4. Involved in spermatogonial } \\
\text { differentiation (Pellegrini et al., 2003) }\end{array}$ & 4 \\
\hline 95471 & $\begin{array}{l}\text { Cyclin-dependent kinase inhibitor } 1 \mathrm{C} \\
\text { (P57) }\end{array}$ & p57 & Absent in spermatocytes. Cdk2 inhibitor & 4 \\
\hline 98067 & $\begin{array}{l}\text { Cyclin-dependent kinase inhibitor } 1 \mathrm{~A} \\
\text { (P21) }\end{array}$ & $\mathrm{p} 21$ & Absent in spermatocytes. Cdk2 inhibitor & 3 \\
\hline 103064 & Checkpoint kinase 1 homolog & Chk1, Chek1, rad27 & $\begin{array}{l}\text { Absent in spermatocytes. Protein kinase, which is } \\
\text { required for the DNA damage checkpoint. In response to } \\
\text { DNA damage, Chk1 phosphorylates and inhibits } \\
\text { Cdc } 25 \mathrm{C} \text {, thus preventing activation of the Cdc } 2 \text {-cyclin } \\
\text { B complex and mitotic entry }\end{array}$ & 3 \\
\hline 160538 & $\begin{array}{l}\text { D-type G1 cyclin catalytic subunit } \\
\text { (PSK-J3/CDK4) }\end{array}$ & $\mathrm{Cdk} 4$ & $\begin{array}{l}\text { Present in spermatocytes. Cell cycle kinase activated } \\
\text { and essential for G1/S transition (Dolci et al., 2001) }\end{array}$ & 2 \\
\hline 160545 & Cyclin D3 & Ccnd3 & $\begin{array}{l}\text { Absent in spermatocytes. Cell cycle control in G1/S } \\
\text { Phase (Dolci et al., 2001) }\end{array}$ & 2 \\
\hline 104154 & Transformation related protein 53 & p53 & $\begin{array}{l}\text { Absent in spermatocytes (marginal in one sample). } \\
\text { Apoptosis inducer and cell cycle control in G1/S Phase }\end{array}$ & 2 \\
\hline 92481 & Checkpoint kinase 2 homolog & Chk2, Chek2, rad53 & $\begin{array}{l}\text { Absent in spermatocytes (marginal in one sample). } \\
\text { ATM-dependent. Function similar to that of Chk1 }\end{array}$ & 2 \\
\hline 99186 & Cyclin A2 & Ccna2 & $\begin{array}{l}\text { Absent in spermatocytes. Mitotic cyclin, active in the } S \\
\text { phase, cdk2 subunit (Dolci et al., 2001) }\end{array}$ & 2 \\
\hline
\end{tabular}

teleangectasia mutated homolog) (Barlow et al., 1998). Between growth factor receptors, $c$-kit (encoding the KL receptor) and Alk3 (encoding the Bmp4 receptor) were confirmed to be expressed in pre-meiotic stages, and not in spermatocytes (Sorrentino et al., 1991; Yoshinaga et al., 1991; Schrans-Stassen et al., 1999; Pellegrini et al., 2003).
As expected, many of the genes selectively expressed in spermatogonia and not in spermatocytes encode proteins involved in the regulation of the mitotic cell cycle (transcription factor E2f1, cyclin-dependent-kinase-inhibitors p57 and p21, cyclin D3, cyclin B1, cyclin A2, cyclindependent-kinase 4), and replicative DNA synthesis (DNA 
polymerase $\alpha$, DNA polymerase $\delta$, DNA primase), generally confirming previously published data (Dolci et al., 2001; Orlando et al., 1989). Between genes encoding proteins involved in pro-apoptotic programs, p53 and Bax were found to be selectively expressed in spermatogonia. The lack of Bax expression in spermatocytes, according to the microarray statistical analysis, is in partial conflict with previously published data (Yan et al., 2000, see below). Bcllo was found to be expressed also in spermatocytes, even though at a much lower level.

As for the targets that gave a higher signal in spermatocytes, we tried to classify them in a series of functional clusters: apoptosis/cell-cycle, chromatin/transcription, cytoskeleton/traffic, meiosis/spermatogenesis,

Table 2

Genes expressed in spermatocytes: apoptosis/cell cycle

\begin{tabular}{|c|c|c|c|c|}
\hline $\begin{array}{l}\text { MG-U74Av2 } \\
\text { target } \\
\text { Affymetrix }\end{array}$ & Gene name & Gene symbol & Notes & $\begin{array}{l}\text { Fold difference } \\
\text { (spermatocytes } \\
\text { vs. spermatogonia) }\end{array}$ \\
\hline 160644 & BCL2-antagonist/killer 1 & Bak1 & $\begin{array}{l}\text { Absent in spermatogonia. Involved in apoptosis; caspase } \\
\text { activation via cytochrome c (Yan et al., 2000) }\end{array}$ & 45 \\
\hline 92911 & Cyclin A1 & Ccnal & $\begin{array}{l}\text { Absent in spermatogonia. In knock-out mice, meiotic arrest } \\
\text { during meiotic divisions (Liu et al., 1998) }\end{array}$ & 23 \\
\hline 99522 & Germ cell-specific gene 2 & Gsg2 & $\begin{array}{l}\text { Absent in spermatogonia (marginal in one sample). Atypical } \\
\text { serine-threonine kinase, named Haspin (for haploid germ } \\
\text { cell-specific nuclear protein kinase) }\end{array}$ & 17 \\
\hline 160761 & $\begin{array}{l}\text { Upregulated during } \\
\text { skeletal muscle growth } 4\end{array}$ & Usmg4 & Absent in spermatogonia & 11 \\
\hline 100054 & DNA segment $\mathrm{Chr} 2$ & D2Wsu81e & $\begin{array}{l}\text { Present in spermatogonia. Endonuclease G: a mitochondrial } \\
\text { protein released in apoptosis and involved in caspase- } \\
\text { independent DNA degradation }\end{array}$ & 10 \\
\hline 92929 & Cytochrome c, testis & Cyct & $\begin{array}{l}\text { Present in spermatogonia. Null mice produce functional sperm } \\
\text { but undergo early testicular atrophy (Narisawa et al., 2002) }\end{array}$ & 10 \\
\hline 94971 & $\begin{array}{l}\text { KAP1, Cdk inhibiting } \\
\text { phosphatase }\end{array}$ & Cdkn3 & $\begin{array}{l}\text { Present in spermatogonia. cdk2-associated dual specificity } \\
\text { phosphatase }\end{array}$ & 9 \\
\hline 94521 & $\begin{array}{l}\text { Cyclin-dependent kinase } \\
\text { inhibitor } 2 \mathrm{D}\end{array}$ & Cdkn2d, Ink4d, p19 & $\begin{array}{l}\text { Absent in spermatogonia. Selective cdk } 4 / 6 \text { inhibitor. Double } \\
\text { p19 and p18 (Ink4c) knock-out provokes sterility due to a } \\
\text { delayed exit of spermatogonia from the mitotic cell cycle } \\
\text { (Zindy et al., 2001) }\end{array}$ & 9 \\
\hline 101885 & Growth arrest specific 5 & Gas5 & $\begin{array}{l}\text { Absent in spermatogonia. Preferentially expressed in the growth } \\
\text { phase arrest of the cell cycle }\end{array}$ & 6 \\
\hline 160638 & $\begin{array}{l}\text { Cyclin-dependent kinase } \\
\text { inhibitor } 2 \mathrm{C}\end{array}$ & Cdkn2c, Ink4c, p18 & $\begin{array}{l}\text { Absent in spermatogonia. Selective cdk } 4 / 6 \text { inhibitor. Double } \\
\text { p19 (Ink4d) and p18 knock-out provokes sterility due to a } \\
\text { delayed exit of spermatogonia from the mitotic cell cycle } \\
\text { (Zindy et al., 2001) }\end{array}$ & 6 \\
\hline 99670 & $\begin{array}{l}\text { Bcl-associated death } \\
\text { promoter }\end{array}$ & $\mathrm{Bad}$ & Absent in spermatogonia. Pro-apoptotic factor (Yan et al., 2000) & 5 \\
\hline 98945 & $\begin{array}{l}\text { SH3-domain GRB2-like } \\
\text { B1 (endophilin) }\end{array}$ & Sh3glb1 & $\begin{array}{l}\text { Present in spermatogonia. Synaptically enriched protein } \\
\text { implicated in synaptic vesicle endocytosis. Might be involved in } \\
\text { apoptotic programs since it interacts with Bax }\end{array}$ & 4 \\
\hline 92879 & $\begin{array}{l}\text { Protein phosphatase } 1 \mathrm{G}, \gamma \\
\text { isoform }\end{array}$ & Ppm1g, PP2C- $\gamma$ & $\begin{array}{l}\text { Present in spermatogonia. Formerly called protein phosphatase } \\
\text { 2C. Magnesium-dependent serine-threonine phosphatase, } \\
\text { known to be expressed in the testis and skeletal muscle }\end{array}$ & 4 \\
\hline 94294 & Cyclin B2 & Ccnb2 & $\begin{array}{l}\text { Present in spermatogonia. Interacts with cdc2 (cdk1) as a } \\
\text { subunit. Component of MPF (Dolci et al., 2001) }\end{array}$ & 4 \\
\hline 104738 & Zuotin related factor 2 & Zrf2 & $\begin{array}{l}\text { Present in spermatogonia. A ribosome-associated DnaJ } \\
\text { molecular chaperone. Also called MIDA-1, associates with Id } \\
\text { HLH transcription factors }\end{array}$ & 3 \\
\hline 102734 & $\begin{array}{l}\text { Baculoviral IAP } \\
\text { repeat-containing } 3\end{array}$ & Birc3, mIAP-2 & $\begin{array}{l}\text { Present in spermatogonia. Also called Apoptosis inhibitor } 2 . \\
\text { Caspase inhibitor }\end{array}$ & 3 \\
\hline 104476 & $\begin{array}{l}\text { Retinoblastoma-like } 1 \\
\text { (p107) }\end{array}$ & Rbl1 & $\begin{array}{l}\text { Absent in spermatogonia (marginal in one sample). Homolog of } \\
\mathrm{pRb} \text {, involved in negative regulation of the cell cycle }\end{array}$ & 2 \\
\hline 101521 & $\begin{array}{l}\text { Baculoviral IAP } \\
\text { repeat-containing } 5\end{array}$ & Birc5, TIAP & $\begin{array}{l}\text { Present in spermatogonia. Homologous to human survivin. } \\
\text { Caspase inhibitor }\end{array}$ & 2 \\
\hline
\end{tabular}


membrane-bound-proteins/receptors, metabolism, RNA binding proteins, signal-transduction/protein-kinases (Tables 2-9). Also in this case, we ordered these genes according to the average Signal Log Ratio parameter, which was converted in average fold difference of the signal in spermatocytes vs. spermatogonia. We also considered whether the target, beside giving a higher signal in spermatocytes, gave a positive (detection parameter: $\mathrm{P}$ ) or negative (detection parameter: A) signal in spermatogonia, and the calculation of the fold difference of the signal between the two cell populations does not take into account whether the target gene is significantly expressed or not in spermatogonia.

For the large majority of these targets, detection of a high signal in spermatocytes by the microarray analysis confirmed data that are available in published literature or in

Table 3

Genes expressed in spermatocytes: chromatin/transcription

\begin{tabular}{|c|c|c|c|c|}
\hline $\begin{array}{l}\text { MG-U74Av2 } \\
\text { target } \\
\text { Affymetrix }\end{array}$ & Gene name & Gene symbol & Notes & $\begin{array}{l}\text { Fold difference } \\
\text { (spermatocytes } \\
\text { vs. spermatogonia) }\end{array}$ \\
\hline 160599 & Testis-specific gene A2 & Tsga2 & $\begin{array}{l}\text { Absent in spermatogonia. Male meiotic metaphase } \\
\text { chromosome-associated acidic protein }\end{array}$ & 56 \\
\hline 102795 & Mesoderm posterior 1 & Mesp1 & Absent in spermatogonia. HLH protein & 42 \\
\hline 161064 & PHD finger protein 7 & Phf7 & $\begin{array}{l}\text { Present in spermatogonia. Isolated from a mouse testis } \\
\text { cDNA library }\end{array}$ & 42 \\
\hline 102079 & Mus musculus Aip1 & Aip1, Aym1 & $\begin{array}{l}\text { Absent in spermatogonia. IME-1 functional homolog } \\
\text { (Personal communication from Jeremy Don, Bar-Ilan } \\
\text { University, Ramat Gan, Israel) }\end{array}$ & 40 \\
\hline 104622 & $\begin{array}{l}\text { Transcription elongation factor A } \\
\text { (SII), } 2\end{array}$ & Tcea2 & Absent in spermatogonia & 34 \\
\hline 97745 & Homeo box A4 & Hoxa4 & Absent in spermatogonia & 29 \\
\hline 95755 & Cold shock domain protein A & Csda & Present in spermatogonia & 25 \\
\hline 93182 & $\begin{array}{l}\text { Glial and testis-specific homeobox } \\
\text { gene }\end{array}$ & Nkx6-2, Gtx & $\begin{array}{l}\text { Absent in spermatogonia. Murine homeobox-containing } \\
\text { gene, expressed specifically in glial cells of the brain and } \\
\text { germ cells of testis. Knock-out mice are viable and } \\
\text { fertile (Cai et al., 2001) }\end{array}$ & 17 \\
\hline 102219 & Regulatory factor X, 2 & $\operatorname{Rfx} 2$ & $\begin{array}{l}\text { Absent in spermatogonia. Influences HLA class II } \\
\text { expression }\end{array}$ & 16 \\
\hline 99987 & RIKEN cDNA A630056B21 gene & A630056B21Rik & $\begin{array}{l}\text { Absent in spermatogonia. Weakly similar to zinc finger } \\
\text { protein } 2(\mathrm{Zfp} 2)(\mathrm{mKR} 2 \text { protein) }\end{array}$ & 15 \\
\hline 98414 & Zinc finger protein 42 & Zfp42 & $\begin{array}{l}\text { Present in one sample in spermatogonia. Expressed also } \\
\text { in embryonic stem cells }\end{array}$ & 14 \\
\hline 160204 & RIKEN cDNA 3110013H01 gene & 3110013H01Rik & $\begin{array}{l}\text { Present in spermatogonia. Nuclear protein } \mathrm{p} 30 \text {, a protein } \\
\text { of the nuclear pore complex }\end{array}$ & 11 \\
\hline 93221 & $\begin{array}{l}\text { RIKEN cDNA 4921540P06 gene } \\
\text { (Homeo box D8) }\end{array}$ & 4921540P06Rik & $\begin{array}{l}\text { Absent in spermatogonia. Other names: Hox-4.3 140, } \\
\text { HOXD8, Hox } 5.4\end{array}$ & 11 \\
\hline 100126 & Chromatin accessibility complex 1 & Chrac1 & $\begin{array}{l}\text { Present in spermatogonia. NF-YC-like protein. Also } \\
\text { called YCL1 (Bolognese et al., 2000) }\end{array}$ & 11 \\
\hline 97893 & $\begin{array}{l}\text { TATA box binding protein-like } \\
\text { protein }\end{array}$ & Tlp & $\begin{array}{l}\text { Present in spermatogonia. Also named TLF, TRF2 or } \\
\text { TBPL1. Knockout mice arrest at spermiogenesis } \\
\text { (Martianov et al., 2001) }\end{array}$ & 9 \\
\hline 92432 & Zinc finger protein 93 & Zfp93 & Absent in spermatogonia & 9 \\
\hline 104604 & Zinc finger protein 96 & Zfp96 & Present in one sample in spermatogonia & 6 \\
\hline 103629 & Lymphoid enhancer binding factor 1 & Lef1 & Absent in spermatogonia & 6 \\
\hline 96144 & Inhibitor of DNA binding 4 & Idb4 & $\begin{array}{l}\text { Absent in spermatogonia. Id } 4 \text {, dominant negative } \\
\text { helix-loop-helix protein }\end{array}$ & 6 \\
\hline 92195 & $\begin{array}{l}\text { CCAAT/enhancer binding protein } \\
(\mathrm{C} / \mathrm{EBP}), \gamma\end{array}$ & Cebpg & Present in spermatogonia & 6 \\
\hline 94406 & $\begin{array}{l}\text { Putative homeodomain transcription } \\
\text { factor }\end{array}$ & Phtf & Present in spermatogonia & 5 \\
\hline 98032 & Zinc finger protein 35 & Zfp35 & Present in spermatogonia & 5 \\
\hline 160220 & Zinc finger protein 110 & Zfp110 & Absent in spermatogonia & 4 \\
\hline 94102 & H6 homeo box 1 & $\operatorname{Hmx} 1$ & Absent in spermatogonia (Yoshiura et al., 1998) & 4 \\
\hline
\end{tabular}


Table 4

Genes expressed in spermatocytes: cytoskeleton/traffic

\begin{tabular}{|c|c|c|c|c|}
\hline $\begin{array}{l}\text { MG-U74Av2 } \\
\text { target } \\
\text { Affymetrix }\end{array}$ & Gene name & Gene symbol & Notes & $\begin{array}{l}\text { Fold difference } \\
\text { (spermatocytes } \\
\text { vs.spermatogonia) }\end{array}$ \\
\hline 99995 & Centrin 1 & Cetn1 & $\begin{array}{l}\text { Absent in spermatogonia. Also called caltractin. } \\
\text { Testis-specific centrosomal protein encoded by an } \\
\text { intronless retroposon }\end{array}$ & 588 \\
\hline 101864 & Actin-like $7 \mathrm{~b}$ & Actl7b & $\begin{array}{l}\text { Absent in spermatogonia. Testis-specific actin isoform, } \\
\text { encoded by an intronless gene }\end{array}$ & 76 \\
\hline 161035 & Kinesin family member 9 & Kif9 & $\begin{array}{l}\text { Absent in spermatogonia. Microtubule motor associated } \\
\text { protein abundantly expressed in the testis }\end{array}$ & 58 \\
\hline 160631 & $\begin{array}{l}\text { Sarcoglycan, } \alpha \text { ( } 50 \mathrm{kDa} \text { dystrophin- } \\
\text { associated glycoprotein) }\end{array}$ & Sgca, adhalin & $\begin{array}{l}\text { Absent in spermatogonia. Integral plasma membrane protein } \\
\text { considered specifically expressed in striated muscle }\end{array}$ & 36 \\
\hline 99531 & Synaptogyrin 4 & Syngr4 & $\begin{array}{l}\text { Absent in spermatogonia. Integral membrane protein } \\
\text { present in synaptic vesicles }\end{array}$ & 36 \\
\hline 101195 & Myosin light chain 2 & Mylc2pl & $\begin{array}{l}\text { Absent in spermatogonia. Considered specifically expressed } \\
\text { in precursor B and } \mathrm{T} \text { lymphocytes }\end{array}$ & 17 \\
\hline 92496 & $\begin{array}{l}\text { Vesicle-associated membrane } \\
\text { protein } 5\end{array}$ & Vamp5 & $\begin{array}{l}\text { Absent in spermatogonia. Also called synaptobrevin. } \\
\text { Expressed during myogenesis in striated muscles }\end{array}$ & 15 \\
\hline 101520 & RIKEN cDNA $1700062 C 23$ gene & 1700062C23Rik & $\begin{array}{l}\text { Absent in spermatogonia. Kinesin-related protein HASH. } \\
\text { Rat homolog known to be expressed during spermatogenesis } \\
\text { in meiotic cells }\end{array}$ & 10 \\
\hline 160487 & $\begin{array}{l}\text { Myosin light chain, alkali, } \\
\text { cardiac atria }\end{array}$ & myla & $\begin{array}{l}\text { Absent in spermatogonia. Expressed during striated muscle } \\
\text { development }\end{array}$ & 9 \\
\hline 103684 & Tektin-2 & Tekt2 & $\begin{array}{l}\text { Absent in spermatogonia. A sperm flagellar protein also } \\
\text { called tektin-t and different from tektin-1 }\end{array}$ & 8 \\
\hline 94321 & Keratin complex 1, acidic, gene 10 & Krt1-10 & $\begin{array}{l}\text { Absent in spermatogonia (marginal in one sample). Protein } \\
\text { of intermediate filaments }\end{array}$ & 4 \\
\hline 95097 & $\begin{array}{l}\text { ARP10 actin-related protein } 10 \\
\text { homolog }\end{array}$ & Actr10 & Present in spermatogonia. Protein of the dynactin complex & 4 \\
\hline 93567 & Profilin 2 & Pfn2 & Present in spermatogonia. Actin binding ubiquitous protein & 4 \\
\hline 102732 & Talin & $\operatorname{tln}$ & Present in spermatogonia. Integrin and actin binding protein & 4 \\
\hline 93499 & Capping protein $\alpha 1$ & cappa1 & Present in spermatogonia. Actin binding protein & 4 \\
\hline 104565 & $\begin{array}{l}\text { Adaptor-related protein complex } \\
\text { AP-4, sigma } 1\end{array}$ & Ap4s1 & $\begin{array}{l}\text { Present in spermatogonia. Adaptor protein of } \\
\text { clathrin-coated vesicles involved in intracellular protein } \\
\text { transport and endocytosis }\end{array}$ & 3 \\
\hline 92643 & Neurofibromatosis 2 & Nf2 & $\begin{array}{l}\text { Present in spermatogonia. Tumor suppressor protein } \\
\text { involved in mediating interactions between the plasma } \\
\text { membrane and the cytoskeleton }\end{array}$ & 3 \\
\hline 93333 & Tubulin cofactor a & Tbca & $\begin{array}{l}\text { Present in spermatogonia. Molecular chaperonin involved in } \\
\text { tubulin folding }\end{array}$ & 2 \\
\hline 103878 & $\begin{array}{l}\text { Adaptor-related protein complex } \\
\text { AP-3, } \beta 1 \text { subunit }\end{array}$ & Ap3b1 & $\begin{array}{l}\text { Present in spermatogonia. Adaptor protein of } \\
\text { clathrin-coated vesicles involved in intracellular protein } \\
\text { transport and endocytosis }\end{array}$ & 2 \\
\hline
\end{tabular}

expression databases, indicating that our analysis faithfully reflected the actual differences in the pattern of gene expression between male mitotic and meiotic germ cells. Many of these genes encode proteins specifically involved in the control of the meiotic cell cycle, such as cyclin A1 (Table 2) (Liu et al., 1998), cdk4-inhibitors p18 and p19 (Table 2) (Zindy et al., 2001), A-myb (Table 2) (Toscani et al., 1997), Nek2 (Table 9) (Di Agostino et al., 2002), but in many cases their expression reflects meiotic accumulation of transcripts destined to be translated later during spermiogenesis, such as testis-specific lactate dehydrogenase (Table 7) (Li et al., 1998), testis-specific poly(A) polymerase $\beta$ (Table 8) Kashiwabara et al., 2002), calmegin (Table 9) (Ikawa et al., 1997), preproacrosin (Table 5) (Kremling et al., 1991), fertilin $\beta$ (Table 5) (Cho et al., 1998), Trf2 (Table 3) (Martianov et al., 2001), MSJ-1 (Table 5) (Berruti and Martegani, 2001), Tpx1 (Table 5) (Kasahara et al., 1989), Tekt1 (Table 5) (Larsson et al., 2000), Tesp1 (Table 5) (Kohno et al., 1998) and so on. It is noteworthy that the spermatocyte-specific expression of a large number of genes encoding enzymes is involved in glycolysis and gluconeogenesis, beside that of $P g k 2$, encoding a well known meiotic isoform of phosphoglycerate kinase (Boer et al., 1987) (Table 7). Thus, metabolic pathways distinct 
Table 5

Genes expressed in spermatocytes: meiosis/spermatogenesis

\begin{tabular}{|c|c|c|c|c|}
\hline $\begin{array}{l}\text { MG-U74Av2 } \\
\text { target } \\
\text { Affymetrix }\end{array}$ & Gene name & Gene symbol & Notes & $\begin{array}{l}\text { Fold difference } \\
\text { (spermatocytes vs. } \\
\text { spermatogonia) }\end{array}$ \\
\hline 160219 & Meiosis expressed gene 1 & Meg1 & Absent in spermatogonia (Don and Wolgemuth, 1992) & 653 \\
\hline 94927 & Fatty acid binding protein 9 & Fabp9, Perf 15 & $\begin{array}{l}\text { Absent in spermatogonia. Perforatorial protein in the } \\
\text { perinuclear theca of spermatozoa }\end{array}$ & 388 \\
\hline 92825 & Testis-specific gene 1 & Tpx1 & Absent in spermatogonia (Kasahara et al., 1989) & 349 \\
\hline 92732 & $\begin{array}{l}\text { A disintegrin and metalloprotease } \\
\text { domain } 2\end{array}$ & Adam2 & $\begin{array}{l}\text { Absent in spermatogonia. Also called Fertilin } \beta \text {. Knock-out } \\
\text { mice are sterile for failure of sperm-egg or sperm-oviduct } \\
\text { interactions (Cho et al., 1998) }\end{array}$ & 256 \\
\hline 103058 & $\mathrm{~T}$-complex protein $10 \mathrm{~b}$ & Tcp10b & Absent in spermatogonia & 238 \\
\hline 99545 & Tektin 1 & Tekt1 & $\begin{array}{l}\text { Absent in spermatogonia. Sperm axonemal protein (Larsson } \\
\text { et al., 2000) }\end{array}$ & 187 \\
\hline 99134 & $\begin{array}{l}\text { T-complex-associated testis } \\
\text { expressed } 3\end{array}$ & Tcte3 & Present in spermatogonia & 163 \\
\hline 93955 & Zona-pellucida-binding protein & Zpbp, sp38 & Absent in spermatogonia & 157 \\
\hline 99474 & $\begin{array}{l}\text { A disintegrin and metalloprotease } \\
\text { domain } 5\end{array}$ & Adam5 & Absent in spermatogonia & 147 \\
\hline 160506 & $\begin{array}{l}\text { A kinase anchoring protein- } \\
\text { associated sperm protein }\end{array}$ & Akapasp & Absent in spermatogonia & 133 \\
\hline 100358 & T-complex protein $10 \mathrm{a}$ & Tcp10a & Absent in spermatogonia & 128 \\
\hline 97381 & T-complex protein 11 & Tcp11 & Absent in spermatogonia & 79 \\
\hline 93207 & Preproacrosin & Acr & Absent in spermatogonia (Kremling et al., 1991) & 52 \\
\hline 160122 & RIKEN cDNA 2410004D18 gene & 2410004D18Rik & $\begin{array}{l}\text { Absent in spermatogonia. Asparaginase-like sperm } \\
\text { autoantigen }\end{array}$ & 50 \\
\hline 97481 & $\begin{array}{l}\text { DnaJ (Hsp40) homolog, subfamily B, } \\
\text { member } 3\end{array}$ & Dnajb3, MSJ-1 & $\begin{array}{l}\text { Absent in spermatogonia. Member of the DNAj co-chaperon } \\
\text { family (Berruti and Martegani, 2001) }\end{array}$ & 42 \\
\hline 99456 & Proacrosin binding protein & Acrbp, sp32 & Absent in spermatogonia & 39 \\
\hline 95299 & Dynein, axonemal, heavy chain 8 & Dnahc8 & $\begin{array}{l}\text { Absent in spermatogonia. Absent also in one sample of } \\
\text { spermatocytes }\end{array}$ & 39 \\
\hline 102244 & Testicular serine protease 1 & Tesp1 & $\begin{array}{l}\text { Absent in spermatogonia. Sperm acrosomal protein } \\
\text { (Kohno et al., 1998) }\end{array}$ & 36 \\
\hline 97785 & DNA segment, human D6S2654E & D0H6S2654E & $\begin{array}{l}\text { Present in one sample of spermatogonia. Also called X5L } \\
\text { protein (XAP5 like protein, retroposon-encoded copy of an } \\
\text { X-linked gene) }\end{array}$ & 30 \\
\hline 100626 & Outer dense fiber 2 & Odf2 & Present in spermatogonia & 16 \\
\hline 103541 & $\begin{array}{l}\text { T-complex-associated testis } \\
\text { expressed } 2\end{array}$ & Tcte 2 & Absent in spermatogonia & 16 \\
\hline 103468 & $\begin{array}{l}\text { Meiosis-specific nuclear structural } \\
\text { protein } 1\end{array}$ & Mns1 & Present in spermatogonia & 12 \\
\hline 102747 & $\begin{array}{l}\text { T-complex-associated testis } \\
\text { expressed } 1\end{array}$ & Tcte 1 & Absent in spermatogonia & 11 \\
\hline 103956 & 5-azacytidine induced gene 1 & Azi1 & Absent in spermatogonia. Pre-acrosomal protein & 10 \\
\hline 102818 & Xlr-related, meiosis regulated & $\mathrm{Xmr}$ & Absent in spermatogonia & 5 \\
\hline 94891 & Male enhanced antigen 1 & Mea1 & Present in spermatogonia & 3 \\
\hline 92888 & $\begin{array}{l}\text { Phosphoserine/threonine/tyrosine } \\
\text { interaction protein }\end{array}$ & Styx & $\begin{array}{l}\text { Present in spermatogonia. Complexes with a testicular } \\
\text { phosphorylated RNA-binding protein and is essential for } \\
\text { normal spermiogenesis (Wishart and Dixon, 2002) }\end{array}$ & 2 \\
\hline 92692 & Synaptonemal complex protein 1 & Sycp1 & Present in spermatogonia & 2 \\
\hline
\end{tabular}

from those operating in mitotic germ cells and somatic cells might drive carbohydrate utilization in meiotic and/or postmeiotic germ cells, even though this hypothesis needs to be substantiated by more specific studies. We also noticed several targets whose relative gene expression in spermatogonia or in spermatocytes was either not known, or controversial, or conflicting with data available in the literature. The pattern of expression in spermatocytes vs. 
Table 6

Genes expressed in spermatocytes: membrane-bound proteins/receptors

\begin{tabular}{|c|c|c|c|c|}
\hline $\begin{array}{l}\text { MG-U74Av2 } \\
\text { target } \\
\text { Affymetrix }\end{array}$ & Gene name & Gene symbol & Notes & $\begin{array}{l}\text { Fold difference } \\
\text { (spermatocytes } \\
\text { vs. spermatogonia) }\end{array}$ \\
\hline 101390 & Mucin 3, intestinal & Muc3 & $\begin{array}{l}\text { Absent in spermatogonia. Glycoprotein of the colon } \\
\text { epithelium }\end{array}$ & 62 \\
\hline 92198 & Decay accelerating factor 2 & Daf2 & $\begin{array}{l}\text { Absent in spermatogonia. Integral membrane protein } \\
\text { involved in complement activation }\end{array}$ & 31 \\
\hline 103289 & $\begin{array}{l}\text { Low density lipoprotein } \\
\text { receptor-related protein } 4\end{array}$ & Lrp4, corin & $\begin{array}{l}\text { Absent in spermatogonia. Atrial natriuteric peptide- } \\
\text { converting enzyme (pro-ANP-converting enzyme). Serine } \\
\text { protease of the trypsin family }\end{array}$ & 10 \\
\hline 103656 & $\begin{array}{l}\text { LanC (bacterial lantibiotic } \\
\text { synthetase component C)-like }\end{array}$ & $\begin{array}{l}\text { Lanc11, p40GPRT, } \\
\text { p40/GPR69A }\end{array}$ & $\begin{array}{l}\text { Present in spermatogonia. Originally proposed as a G- } \\
\text { protein coupled receptor, was then characterized as a loosely } \\
\text { membrane-associated protein related to the LanC family of } \\
\text { bacterial proteins involved in the biosynthesis of } \\
\text { antimicrobial peptides }\end{array}$ & 8 \\
\hline 160876 & $\begin{array}{l}\text { B-cell receptor-associated } \\
\text { protein } 29\end{array}$ & Bcap29 & $\begin{array}{l}\text { Present in spermatogonia. Associated with the membrane } \\
\text { IgD and IgM receptors in B lymphocytes }\end{array}$ & 8 \\
\hline 100438 & G protein coupled receptor 19 & Gpr19 & $\begin{array}{l}\text { Absent in spermatogonia. G-protein coupled receptor for an } \\
\text { unknown ligand (O'Dowd et al., 1996) }\end{array}$ & 4 \\
\hline 99160 and 99161 & $\begin{array}{l}\text { RIKEN cDNA } 1110025 \mathrm{~J} 15 \\
\text { gene }\end{array}$ & 1110025J15Rik & $\begin{array}{l}\text { Present in spermatogonia. Similar to membrane proteins } \\
\text { related to a glutamate binding protein (NMDA receptor) }\end{array}$ & 4 \\
\hline 102343 & Hypothetical protein $425018-1$ & $425018-1$ & $\begin{array}{l}\text { Present in spermatogonia. Contains a low density } \\
\text { lipoprotein-receptor class A domain }\end{array}$ & 4 \\
\hline 103726 & $\begin{array}{l}\text { RIKEN cDNA } 2610311119 \\
\text { gene }\end{array}$ & 2610311I19Rik & $\begin{array}{l}\text { Absent in spermatogonia. Similar to Golgi membrane } \\
\text { protein SB140. I }\end{array}$ & 3 \\
\hline 161046 & Cytokine receptor-like factor 1 & Crlf1 & $\begin{array}{l}\text { Present in spermatogonia. Soluble cytokine receptor subunit } \\
\text { or part of a cytokine responsive complex, possibly playing a } \\
\text { regulatory role in the immune system and during fetal } \\
\text { development }\end{array}$ & 2 \\
\hline
\end{tabular}

spermatogonia for a selection of these genes is shown in Fig. 2. Northern blot analysis confirmed both qualitatively and quantitatively the data obtained by the microarray experiments.

An expression pattern in partial conflict with previously published data was particularly evident for several proapoptotic members of the $\mathrm{Bcl} 2$ family. Bad was previously reported to be expressed in spermatogonia and in Sertoli cells, but not in spermatocytes, nor in spermatids (Yan et al., 2000), while both microarray and Northern blot analysis showed that Bad mRNA is expressed in spermatocytes, but not in spermatogonia, nor in Sertoli cells (Table 2 and Fig. 2). Moreover, its expression was very strong in spermatids, in which a slower migrating transcript was observed. Bak was reported to be expressed in Sertoli cells, in spermatogonia and in spermatocytes, but not in spermatids (Yan et al., 2000), but we found a very abundant transcript only in meiotic and post-meiotic cells, and no expression in spermatogonia, nor in Sertoli cells (Table 2 and Fig. 2). Interestingly it has been recently reported that apoptosis-like mechanisms are required for spermatid differentiation in Drosophila (Arama et al., 2003). An analogy between cytoplasmic apoptotic events and the formation of residual bodies has been also noticed in mammalian spermiogenesis (Blanco-Rodriguez and Martinez-Garcia, 1999). On the other hand, Bax was reported to be expressed, besides in spermatogonia and Sertoli cells, also in spermatocytes (Yan et al., 2000), but we found an abundant transcript in mitotic germ cells and in Sertoli cells, with the highest level of expression at $7 \mathrm{dpn}$, whereas only a very faint signal was detectable in spermatocytes (Table 1 and Fig. 2).

Chrac1 (chromatin accessibility complex 1, also named Ycl1) is a histone-fold protein that interacts with other histone-fold proteins to bind DNA in a sequence-independent manner. These histone-fold protein dimers combine within larger enzymatic complexes for DNA transcription, replication, and packaging (Bolognese et al., 2000). Chracl mRNA was found to be very abundant in spermatocytes (Table 3 and Fig. 2), suggesting that it might be involved in chromatin remodeling during the first meiotic prophase. This might help to regulate changes in gene expression patterns that characterize specific developmental events during spermatogenesis.

In the cluster of membrane-bound proteins and receptors, microarray analysis revealed the unexpected expression of 
Table 7

Genes expressed in spermatocytes: metabolism

\begin{tabular}{|c|c|c|c|c|}
\hline $\begin{array}{l}\text { MG-U74Av2 } \\
\text { target } \\
\text { Affymetrix }\end{array}$ & Gene name & Gene symbol & Notes & $\begin{array}{l}\text { Fold difference } \\
\text { (spermatocytes vs. } \\
\text { spermatogonia) }\end{array}$ \\
\hline 93103 & $\begin{array}{l}\text { Lactate dehydrogenase } 3, \mathrm{C} \\
\text { chain, sperm specific }\end{array}$ & Ldh3 & $\begin{array}{l}\text { Absent in spermatogonia. Glycolysis and gluconeogenesis } \\
\text { (Li et al., 1998) }\end{array}$ & 3565 \\
\hline 92599 & Phosphoglycerate mutase 2 & Pgam2 & Absent in spermatogonia. Glycolysis and gluconeogenesis & 1260 \\
\hline 96918 & Fructose bisphosphatase 1 & Fbp1 & Absent in spermatogonia. Glycolysis and gluconeogenesis & 401 \\
\hline 92292 & $\begin{array}{l}\text { Solute carrier family } 2 \\
\text { (facilitated glucose transporter), } \\
\text { member } 3\end{array}$ & Slc2a3 & Absent in spermatogonia & 132 \\
\hline 95060 & $\begin{array}{l}\text { Solute carrier family } 16 \\
\text { (monocarboxylic acid } \\
\text { transporters), member } 7\end{array}$ & Slc16a7 & Absent in spermatogonia & 68 \\
\hline 93560 & $\begin{array}{l}\text { RIKEN cDNA } 1110039014 \\
\text { gene }\end{array}$ & 1110039O14Rik & Present in spermatogonia. Similar to human acylphosphatase & 59 \\
\hline 103982 & $\begin{array}{l}\text { Alcohol dehydrogenase } 4 \text { (class } \\
\text { II), pi polypeptide }\end{array}$ & Adh4 & Absent in spermatogonia. Glycolysis and gluconeogenesis & 43 \\
\hline 104328 & Aquaporin 9 & Aqp9 & Absent in spermatogonia. Water transport & 43 \\
\hline 104372 & $\begin{array}{l}\text { RIKEN cDNA 0910001L24 } \\
\text { gene }\end{array}$ & 0910001L24Rik & Absent in spermatogonia. Xenobiotic metabolism & 39 \\
\hline 99011 & $\begin{array}{l}\text { UDP-N-acetyl- } \alpha \text {-D- } \\
\text { galactosamine:polypeptide } \\
\mathrm{N} \text {-acetylgalactosaminyl- } \\
\text { transferase } 3\end{array}$ & Galnt3 & Absent in spermatogonia & 39 \\
\hline 103646 & Carnitine acetyltransferase & Crat & Present in one sample in spermatogonia. Fatty acid metabolism & 33 \\
\hline 101388 & Phosphoglycerate kinase 2 & Pgk2 & $\begin{array}{l}\text { Absent in spermatogonia. Spermatocyte-specific PGK isoform } \\
\text { encoded by an intronless retroposon (Boer et al., 1987). Glycolysis } \\
\text { and gluconeogenesis }\end{array}$ & 33 \\
\hline 99542 & Pyruvate dehydrogenase E1 $\alpha 2$ & Pdha2 & Present in spermatogonia. Glycolysis and gluconeogenesis & 30 \\
\hline 94540 & $\begin{array}{l}\text { RIKEN cDNA 1300006E06 } \\
\text { gene }\end{array}$ & 1300006E06Rik & $\begin{array}{l}\text { Absent in spermatogonia. Cytochrome C P-450-16 } \alpha \text {. Electron } \\
\text { transport }\end{array}$ & 22 \\
\hline 161243 & $\begin{array}{l}\text { RIKEN cDNA 0910001L24 } \\
\text { gene }\end{array}$ & 0910001L24Rik & Absent in spermatogonia. Xenobiotic metabolism & 17 \\
\hline 103531 & $\begin{array}{l}\text { RIKEN cDNA 1300013B24 } \\
\text { gene }\end{array}$ & 1300013B24Rik & $\begin{array}{l}\text { Absent in spermatogonia. Low similarity to endoplasmic } \\
\text { oxidoreductase } 1 \beta\end{array}$ & 16 \\
\hline 92841 & Chromogranin B & Chgb & Absent in spermatogonia & 16 \\
\hline 103068 & $\begin{array}{l}\text { Aldo-keto reductase family } 1 \text {, } \\
\text { member E1 }\end{array}$ & Akr1e1 & Absent in spermatogonia. Aldehyde reductase & 15 \\
\hline 99591 & Retinol dehydrogenase 11 & Rdh11 & $\begin{array}{l}\text { Absent in spermatogonia. Similar to human androgen-regulated } \\
\text { prostate short-chain dehydrogenase/reductase } 1\end{array}$ & 15 \\
\hline 93557 & Selenophosphate synthetase 2 & Sps2 & Absent in spermatogonia & 13 \\
\hline 97511 & Monoglyceride lipase & Mgll & Absent in spermatogonia & 13 \\
\hline 97834 & Phosphofructokinase-1 C & Pfkp & Absent in spermatogonia. Glycolysis and gluconeogenesis & 12 \\
\hline 160839 & $\begin{array}{l}\text { Solute carrier family } 2 \\
\text { (facilitated glucose transporter), } \\
\text { member } 5\end{array}$ & Slc2a5 & Absent in spermatogonia & 11 \\
\hline 96072 & $\begin{array}{l}\text { Lactate dehydrogenase } 1, \mathrm{~A} \\
\text { chain }\end{array}$ & Ldh1e & Present in spermatogonia. Glycolysis and gluconeogenesis & 11 \\
\hline
\end{tabular}

the transcript encoding mucin3, a protein known to be specifically expressed in the colon epithelium (Table 6). Northern blot analysis confirmed high levels of expression of mucin 3 mRNA in spermatocytes, and, at a lesser extent, in spermatids (Fig. 2). Interestingly, another component of the mucosal glycocalyx, contributing to anti-adhesive and protective cell functions, mucin1, has been reported to be expressed in maturing germ cells of the human testis (Franke et al., 2001), and a mucin glycoprotein was found to be an universal constituent of stable intercellular bridges in the Drosophila melanogaster germ line (Kramerova and Kramerov, 1999). 
Table 8

Genes expressed in spermatocytes: RNA binding proteins

\begin{tabular}{|c|c|c|c|c|}
\hline $\begin{array}{l}\text { MG-U74Av2 } \\
\text { target } \\
\text { Affymetrix }\end{array}$ & Gene name & Gene symbol & Notes & $\begin{array}{l}\text { Fold difference } \\
\text { (spermatocytes vs. } \\
\text { spermatogonia) }\end{array}$ \\
\hline 101938 & $\begin{array}{l}\text { Poly(A) binding protein, } \\
\text { cytoplasmic } 2\end{array}$ & Pabpc2 & $\begin{array}{l}\text { Absent in spermatogonia. Encoded by an intronless retroposon } \\
\text { during spermatogenesis }\end{array}$ & 94 \\
\hline 104440 & $\mathrm{Y}$ box protein 2 & Ybx2 & $\begin{array}{l}\text { Absent in spermatogonia. RNA-binding protein which might delay } \\
\text { polysomal association of transcripts during spermiogenesis }\end{array}$ & 90 \\
\hline 97661 & $\begin{array}{l}\text { Testis nuclear RNA binding } \\
\text { protein }\end{array}$ & Tenr & $\begin{array}{l}\text { Present in spermatogonia. Expressed in meiotic and haploid male } \\
\text { germ cells }\end{array}$ & 11 \\
\hline 161041 and 92678 & $\begin{array}{l}\text { DEAD/H (Asp-Glu-Ala- } \\
\text { Asp/His) box polypeptide } 25\end{array}$ & $\operatorname{Ddx} 25$ & $\begin{array}{l}\text { Present in spermatogonia. Gonadotropin regulated RNA helicase } \\
\text { also expressed in Leydig cells }\end{array}$ & 11 \\
\hline 160429 & NTF2-related export protein 1 & Nxt1 & $\begin{array}{l}\text { Present in spermatogonia. RAN-binding protein involved in nuclear } \\
\text { RNA export from the nucleus }\end{array}$ & 7 \\
\hline 100720 & $\begin{array}{l}\text { Poly(A) binding protein, } \\
\text { cytoplasmic } 1\end{array}$ & Pabpc1 & Present in spermatogonia & 4 \\
\hline 101579 & $\begin{array}{l}\text { Signal recognition particle } \\
9 \mathrm{kDa}\end{array}$ & Srp9 & $\begin{array}{l}\text { Present in spermatogonia. Cytoplasmic ribonucleoprotein targeting } \\
\text { nascent polypeptide chains to the endoplasmic reticulum }\end{array}$ & 4 \\
\hline 103101 & $\begin{array}{l}\text { TAR (HIV) RNA binding } \\
\text { protein } 2\end{array}$ & Tarbp2, Prbp & $\begin{array}{l}\text { Present in spermatogonia. Interacts with the } 3^{\prime} \text { untranslated region } \\
\text { of the Protamine- } 1 \text { RNA }\end{array}$ & 4 \\
\hline 101519 & $\begin{array}{l}\text { Signal recognition particle } \\
14 \mathrm{kDa} \text { (homologous Alu } \\
\text { RNA binding protein) }\end{array}$ & Srp14 & $\begin{array}{l}\text { Present in spermatogonia. Cytoplasmic ribonucleoprotein targeting } \\
\text { nascent polypeptide chains to the endoplasmic reticulum }\end{array}$ & 3 \\
\hline 94552 & Poly $(\mathrm{rC})$ binding protein 1 & Pcbp1 & Present in spermatogonia. Implicated in mRNA stabilization & 2 \\
\hline 103330 & $\begin{array}{l}\text { Spermatid perinuclear RNA } \\
\text { binding protein }\end{array}$ & Spnr & $\begin{array}{l}\text { Present in spermatogonia. Binds to the to the } 3^{\prime} \text { UTR of Protamine- } 1 \\
\text { mRNA. Microtubule-associated RNA-binding protein that localizes } \\
\text { to the manchette in developing spermatids }\end{array}$ & 2 \\
\hline
\end{tabular}

Few receptors for potential growth factors were found to be expressed in spermatocytes through the microarray analysis. One of these was Gpr19 (O'Dowd et al., 1996), a seven transmembrane G-coupled receptor for an unknown ligand (Table 6). Northern blot analysis showed an high abundance of the Gpr19 transcript in spermatocytes, a lower level of expression in spermatids, while a faint band was observed in spermatogonia from 7-day, but not 4-day-old mice (Fig. 2). This receptor might thus play a role in the regulation of meiotic entry and/or meiotic progression. The gene encoding Ranbp9 (Ran binding protein 9), a protein shown to be a positive regulator of Ras function (Wang et al., 2002), was found to be highly expressed in spermatids, with a complex migratory pattern, but the signals were evident also in spermatocytes, implying its possible involvement in the regulation of the Ras/MEK/ERK cascade during the transition through the meiotic divisions and/or the morphogenetic events of spermiogenesis (Table 9 and Fig. 2).

Finally, in the cluster of transcription factors (Table 3) we confirmed through Northern blot analysis the selective germ cell expression starting from the meiotic stage of $H m x l$, a homeodomain gene previously not known to be expressed during spermatogenesis (Yoshiura et al., 1998), and of a transcript corresponding to RIKEN cDNA A630056B21Rik (Affymetrix target 99987_at in the MGU74Av2 array) predicted to encode a novel zinc finger protein (Fig. 2). These transcription factors might play an important role in driving the spermatogenic program. As in the case of Ranbp9, the signal generated by the 99987 target in Northern blots was rather complex: this might be due to either the presence of multiple alternative transcripts, or to cross-hybridization with closely related RNAs.

Even though, recently, an initial microarray screen of spermatogenic cells at different developmental stages has been reported ( $\mathrm{Yu}$ et al., 2003), only 1176 mouse target genes were represented in these arrays. We noticed partial overlapping of our data with the ones published by $\mathrm{Yu}$ et al. (2003), but also some discrepancies were evident: for instance, cyclin D3 was reported to be not expressed in spermatogonia, but present in spermatocytes. One should note that we used oligonucleotide based DNA chips, in which each gene is represented by 16 couples of probes and mismatch probes, whereas in the gene arrays used by $\mathrm{Yu}$ et al. each target gene is represented by a single longer 
Table 9

Genes expressed in spermatocytes: signal transduction/protein kinases

\begin{tabular}{|c|c|c|c|c|}
\hline $\begin{array}{l}\text { MG-U74Av2 } \\
\text { target } \\
\text { Affymetrix }\end{array}$ & Gene name & Gene symbol & Notes & $\begin{array}{l}\text { Fold difference } \\
\text { (spermatocytes vs. } \\
\text { spermatogonia) }\end{array}$ \\
\hline 104029 & Calmegin & Clgn & $\begin{array}{l}\text { Absent in spermatogonia. Knockout male mice are sterile for } \\
\text { defective sperm function (Ikawa et al., 1997) }\end{array}$ & 52 \\
\hline 101850 & Sperm autoantigenic protein 17 & Spa17 & $\begin{array}{l}\text { Present in spermatogonia. A calmodulin-binding protein enriched in } \\
\text { the sperm acrosome and interacting with the zona pellucida }\end{array}$ & 31 \\
\hline 100972 & $\begin{array}{l}\text { Chemokine (C-C motif) ligand } \\
27\end{array}$ & $\mathrm{Ccl} 27$ & $\begin{array}{l}\text { Absent in spermatogonia. Also called ALP, CTAK, mILC, CTACK, } \\
\text { PESKY, ESkine, skinkine }\end{array}$ & 29 \\
\hline 102948 & hematopoietic cell transcript 1 & Hemt 1 & $\begin{array}{l}\text { Absent in spermatogonia. Contains a calcium-activated BK } \\
\text { potassium channel } \alpha \text { subunit signature }\end{array}$ & 26 \\
\hline 99869 & $\begin{array}{l}\text { Hepatoma-derived growth } \\
\text { factor }\end{array}$ & HRP1, Pwwp1 & $\begin{array}{l}\text { Absent in spermatogonia. Also called PWWP domain containing } 1 . \\
\text { Present in the nucleus of spermatocytes and spermatids }\end{array}$ & 23 \\
\hline 103489 & Socius & Soc & $\begin{array}{l}\text { Absent in spermatogonia. A Rho-related GTPase-interacting } \\
\text { protein involved in disassembly of actin stress fibers }\end{array}$ & 22 \\
\hline 93210 & NIMA-related-kinase 4 & Nek4 & Absent in spermatogonia & 18 \\
\hline 93658 & $\begin{array}{l}\text { Protein tyrosine phosphatase, } \\
\text { non-receptor type } 20\end{array}$ & Ptpn20 & Absent in spermatogonia & 16 \\
\hline 100287 & $\begin{array}{l}\text { Immunoglobulin (CD79A) } \\
\text { binding protein } 1 \mathrm{~b}\end{array}$ & Igbp1b & $\begin{array}{l}\text { Absent in spermatogonia. Binds to protein phosphatase } 2 \mathrm{~A} \text {. Also } \\
\text { called } \alpha 4-\mathrm{b}\end{array}$ & 16 \\
\hline 160623 & Cyclin-dependent kinase-like 2 & Cdk12 & $\begin{array}{l}\text { Absent in spermatogonia. CDC2-related kinase also called } \\
\text { KKIAMRE }\end{array}$ & 13 \\
\hline 104166 & Renal tumor antigen & Rage, MOK & $\begin{array}{l}\text { Absent in spermatogonia. Protein kinase with homologies with } \\
\text { members of the MAPK family }\end{array}$ & 13 \\
\hline 104135 & ADP-ribosylation-like 3 & Arl3 & $\begin{array}{l}\text { Present in spermatogonia. Small monomeric GTPase of the Ras } \\
\text { superfamily }\end{array}$ & 12 \\
\hline 160948 & $\begin{array}{l}\text { Testis-specific calcineurin } \\
\text { isoform }\end{array}$ & Ppp3cc & $\begin{array}{l}\text { Present in spermatogonia. Calmodulin-dependent protein } \\
\text { phosphatase }\end{array}$ & 11 \\
\hline 100562 & $\begin{array}{l}\text { Ran. guanine nucleotide release } \\
\text { factor }\end{array}$ & Rangnrf & Present in one sample in spermatogonia. Also called MOG1 & 9 \\
\hline 100291 & Casitas B-lineage lymphoma & $\mathrm{Cbl}$ & Absent in spermatogonia. Adaptor protein & 8 \\
\hline 102033 & Testis-specific protein kinase 1 & Tesk1 & Absent in spermatogonia & 8 \\
\hline 92639 & Serine/threonine kinase 6 & Stk6, Ayk1 & $\begin{array}{l}\text { Present in spermatogonia. Also called Aurora/IPL1-related kinase } 1 . \\
\text { Specifically expressed in meiotic cells just before the first meiotic } \\
\text { division }\end{array}$ & 7 \\
\hline 100885 & NIMA-related kinase 2 & Nek2 & $\begin{array}{l}\text { Present in spermatogonia. Involved in chromosome condensation } \\
\text { during meiotic divisions (Di Agostino et al., 2002). Controls } \\
\text { splitting of duplicated centrosomes }\end{array}$ & 7 \\
\hline 161575 & $\begin{array}{l}\text { Mitogen activated protein } \\
\text { kinase } 10\end{array}$ & Mapk10, & $\begin{array}{l}\text { Absent in spermatogonia. Also called SAPK }(\beta), \text { JNK3, SERK2, } \\
\text { p54bSAPK, p439F12 }\end{array}$ & 4 \\
\hline 97812 & RAN binding protein 9 & Ranbp9 & $\begin{array}{l}\text { Present in spermatogonia. Stimulates Ras activation by recruiting } \\
\text { Sos. Also called RanbpM (Wang et al., 2002) }\end{array}$ & 4 \\
\hline
\end{tabular}

oligonucleotide, making the possibility of cross-hybridization easier and hindering the statistical evaluation of the generated signals (see also Section 2). In conclusion, our results represent a first extensive attempt to delineate the global patterns of gene expression characterizing male germ cell differentiation, and should be extended to other germ cell types, namely spermatogonial stem cells and spermatids.

\section{Experimental procedures}

\subsection{Cell preparations}

Germ cell populations highly enriched in mitotic spermatogonia were obtained as previously described from testes of 4-7-day-old mice (Rossi et al., 1993; Pellegrini et al., 2003; Dolci et al., 2001). Briefly, germ 


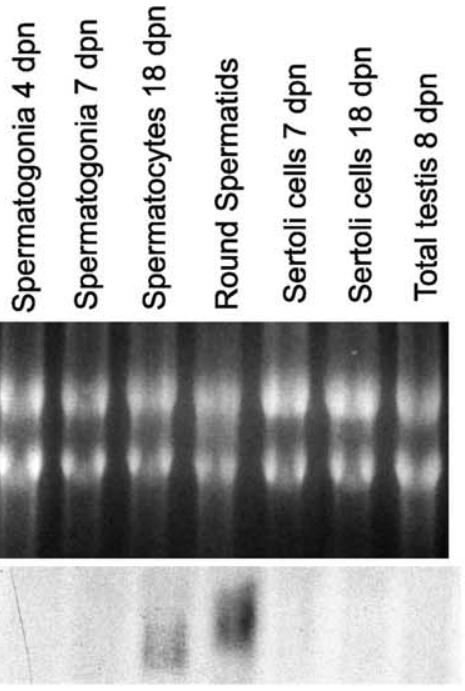

bak

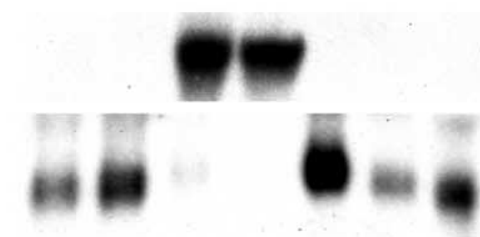

bax
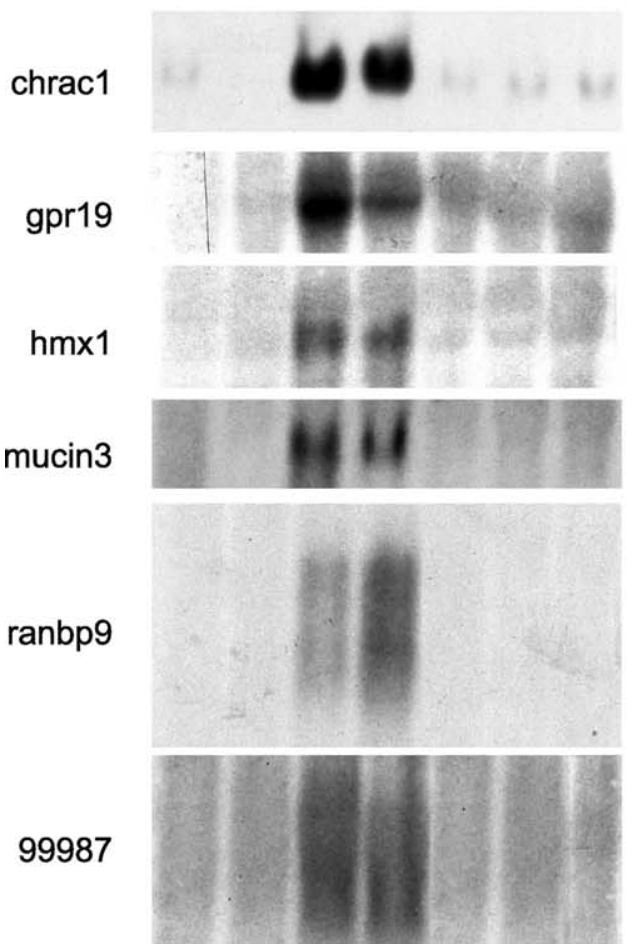

Fig. 2. Germ cell-type-specific expression of a selection of genes identified by Affymetrix microarray hybridizations was verified by Northern blot analysis, using $10 \mu \mathrm{g}$ of total RNA for each indicated testicular cell type. The representative top panel shows ethidium bromide staining, indicating that RNA loading was qualitatively and quantitatively comparable for each sample. Specific labeled gene probes for hybridization were obtained by nick translation of RT-PCR amplified cDNAs, as indicated in Section 2. These Northern blots are representative of at least two experiments, which gave similar results. cell suspensions were obtained by sequential collagenasehyaluronidase-trypsin digestions of freshly withdrawn testes. A $3 \mathrm{~h}$ period of culture in E-MEM additioned with $10 \%$ FCS was performed to facilitate adhesion of contaminating somatic cells to the plastic dishes. At the end of this pre-plating treatment, enriched mitotic germ cell suspensions were rinsed from FCS. Purity of $7 \mathrm{dpn}$ spermatogonia was about $90 \%$ after the pre-plating treatment, whereas a $50 \%$ enrichment was obtained for $4 \mathrm{dpn}$ spermatogonia. The homogeneity of the cell populations was assessed through both morphological criteria and by specific immunostaining with antibodies directed against three specific markers of mitotic germ cells, which are not expressed in testicular somatic cells (Smad5, Alk3 and c-kit). Homogeneous populations (purity $>90 \%$ ) of spermatocytes and round spermatids were obtained from testes of either 18-day-old or 36-day-old mice, respectively, by differential elutriation as previously described (Sette et al., 1999; Di Agostino et al., 2002). Spermatocyte populations from 18-day-old mice ( $10 \%$ at the leptotene-zygotene and $85 \%$ at the middle-late pachytene stage of the meiotic prophase) are devoid of round spermatids, which contaminate elutriation fractions from adult animals, and their purity was assessed through morphological criteria (namely, cell size and the characteristic aspect of partially condensed meiotic chromatin). Sertoli cell monolayers from 7 to 17 -day-old mice, devoid of contaminating germ cells, were prepared as previously described (Grimaldi et al., 1993).

\subsection{RNA extraction, $c D N A$ and $c R N A$ preparation}

RNA was purified by adding cold Trizol reagent (Invitrogen) to freshly prepared cell samples and extracted according to the manufacturer's instructions.

Total cellular RNA (25 $\mu \mathrm{g})$ was used to synthesize cDNA using the cDNA Synthesis Kit (Life Technologies BRL 11917-010) and T7-(dT) 24 oligonucleotide (5'-GGCCAGTGAATTGTAATACGACTCACTATAGGGAGGCGG-(dT) $\left.{ }_{24}-3^{\prime}\right)$ according to manufacturer's instructions. Second strand cDNA was synthesized by adding $10 \mathrm{U}$ of DNA ligase, $40 \mathrm{U}$ of DNA polymerase and $2 \mathrm{U}$ of $\mathrm{RNaseH}$ and incubating at $16^{\circ} \mathrm{C}$ for additional $2 \mathrm{~h}$. At the end of the incubation, $20 \mathrm{U}$ of T4 DNA polymerase were added to the reaction and incubated for $5 \mathrm{~min}$ at the same temperature. Reactions were stopped by adding EDTA (30 mM final concentration). Double stranded cDNA was purified by phenol/chloroform extraction followed by precipitation with 0.5 volumes of $7.5 \mathrm{M}$ ammonium acetate and 2.5 volumes of ethanol and its concentration measured by optical densitometry.

Complementary RNA (cRNA) synthesis was performed using the Essential ENZO kit (Bioarray High Yield TNA transcription kit 900182) and following manufacturer's instructions. The resulting cRNA was purified using QIAGEN Rneasy spin columns (74103) and the standard procedure. RNA was then precipitated as described above 
for cDNA, resuspended in $15 \mu$ of RNase-free $\mathrm{H}_{2} \mathrm{O}$ and quantified by optical densitometry. cRNA was then fragmented in a Tris-acetate buffer $(200 \mathrm{mM}, \mathrm{pH} 8.1)$ containing $500 \mathrm{mM} \mathrm{KOAc}$ and $150 \mathrm{mM} \mathrm{MgOAc}$ by incubation at $94{ }^{\circ} \mathrm{C}$ for $35 \mathrm{~min}$. At the end of the incubation, fragmented cRNA was stored at $-80{ }^{\circ} \mathrm{C}$ until hybridization.

\subsection{DNA microarray analysis}

cRNA samples from two independent cell preparations were used for hybridization to duplicate mouse MG-U74Av2 microarray sets from Affymetrix. This array represents approximately 12,500 murine genes or EST sequences. In each array, target genes are represented by 16 pairs (exact match and single base mismatch) of 25-mer oligonucleotides for each gene. The signals of the pairs are compared to assess specificity of hybridization, thus, beside the intensity of the signal, its statistical significance can be estimated. Biotinylated cRNA $(15 \mu \mathrm{g})$ was hybridized to the array and then processed following the standard Affymetrix protocol. Phycoerythrin-coupled avidin bound microarrays were scanned with a HewlettPackard Gene Array Scanner (Hewlett-Packard Co., Palo Alto, CA), and the results were analyzed using the Affymetrix MAS5 statistical algorithm. For more informations about the statistical analysis, see the Affymetrix Statistical Algorithms Reference Guide at http://www. affymetrix.com/support/technical/technotes/statistical_ reference_guide.pdf.

Target genes represented in the MG-U74Av2 Affymetrix chips were grouped in several functional clusters by using specific keywords with the Interacting Query online facility at www.affymetrix.com.

\subsection{RT-PCR preparation of probes and Northern blot analysis}

cDNA probes for Northern blot hybridization of total RNAs were prepared by RT-PCR amplification of selected mRNAs, by using specific oligonucleotide primers designed on the basis of the sequence of the corresponding Affymetrix target genes. Specificity of the primers was previously controlled through BLAST analysis (http:// www.ncbi.nlm.nih.gov/blast/). The couples of primers used were: TAGCCCTTTTCGAGGACGCTCG and TGGAGCCTCCTTTGCCCAAGTT (for $\mathrm{Bad}$, amplification product $220 \mathrm{bp}$ ); AGTTGGCTCTCAAGGATGGCTT and TCGTTGCACTGACAGAATCTTC (for Bakl, 229 bp); ACCAAGAAGCTGAGCGAGTGT and TCCAGCCCATGATGGTTCTGAT (for Bax, $253 \mathrm{bp}$ ); ATCTGGAGAATAGGCACGGACG and CCGAAATGCCCACATAGTTTCT (for $g p r 19,378 \mathrm{bp}$ ); TGCTCTACAGTGTACCGGACAG and CAGCACTCTGTACTGTCCCTTG (for $h m x l, 291 \mathrm{bp}$ ); GACTCTGTGTACAACACCTTCC and GCCCTTGTAAAGACAGA
TGGTC (for mucin3, $524 \mathrm{bp}$ ); CAAATTGGGAGCTGTTCCGACC and CTACAACAGAAGTCATCTGTAG (for Ranbp9, $267 \mathrm{bp}$ ); TGTGTAGCCG GGAGTTTGGTA and TGAAAACGGACTCCGCACTCCT (for A630056B21Rik, $357 \mathrm{bp}$ ). The cDNA probe for Chracl was kindly provided by Prof. Roberto Mantovani (University of Milan).

cDNAs were labeled by random priming with $\alpha{ }^{32}$ PdNTPs and hybridized using standard conditions to blotted total RNA samples. After stringency washes, blots were exposed overnight at $-80{ }^{\circ} \mathrm{C}$ with intensifier screens for autoradiography.

\section{Acknowledgements}

Due to space restrictions, we apologize for not being able to cite all the relevant papers describing germ cell-specificexpression of several genes that we have confirmed through microarray analysis and included in our tables. We thank Prof. Roberto Mantovani (University of Milan) for supplying a Chracl cDNA probe. This work has been supported by MIUR CoFin 2002, by a grant of 'Centro di Eccellenza per lo Studio del Rischio Genomico in Patologie Complesse Multifattoriali' and by Agenzia Spaziale Italiana.

\section{References}

Arama, E., Agapite, J., Steller, H., 2003. Caspase activity and a specific cytochrome $\mathrm{C}$ are required for sperm differentiation in Drosophila. Dev. Cell 4, 687-697.

Barlow, C., Liyanage, M., Moens, P.B., Tarsounas, M., Nagashima, K., Brown, K., et al., 1998. Atm deficiency results in severe meiotic disruption as early as leptonema of prophase I. Development 125, 4007-4017.

Berruti, G., Martegani, E., 2001. MSJ-1, a mouse testis-specific DnaJ protein, is highly expressed in haploid male germ cells and interacts with the testis-specific heat shock protein Hsp70-2. Biol. Reprod. 65, $488-495$.

Blanco-Rodriguez, J., Martinez-Garcia, C., 1999. Apoptosis is physiologically restricted to a specialized cytoplasmic compartment in rat spermatids. Biol. Reprod. 61, 1541-1547.

Blume-Jensen, P., Jiang, G., Hyman, R., Lee, K.F., O'Gorman, S., Hunter, T., 2000. Kit/stem cell factor receptor induced activation of phosphatidylinositol $3^{\prime}$-kinase is essential for male fertility. Nat. Genet. 24, 157-162.

Boer, P.H., Adra, C.N., Lau, Y.F., McBurney, M.W., 1987. The testisspecific phosphoglycerate kinase gene pgk-2 is a recruited retroposon. Mol. Cell. Biol. 7, 3107-3112.

Bolognese, F., Imbriano, C., Caretti, G., Mantovani, R., 2000. Cloning and characterization of the histone-fold proteins YBL1 and YCL1. Nucleic Acids Res. 28, 3830-3838.

Cai, J., Qi, Y., Wu, R., Modderman, G., Fu, H., Liu, R., Qiu, M., 2001. Mice lacking the Nkx6.2 (Gtx) homeodomain transcription factor develop and reproduce normally. Mol. Cell. Biol. 21, 4399-4403.

Cho, C., Bunch, D.O., Faure, J.E., Goulding, E.H., Eddy, E.M., Primakoff, P., Myles, D.G., 1998. Fertilization defects in sperm from mice lacking fertilin beta. Science 281, 1857-1859.

Di Agostino, S., Rossi, P., Geremia, R., Sette, C., 2002. The MAPK pathway triggers activation of Nek2 during chromosome condensation in mouse spermatocytes. Development 129, 1715-1727. 
Dix, D.J., Allen, J.W., Collins, B.W., Mori, C., Nakamura, N., PoormanAllen, P., et al., 1996. Targeted gene disruption of Hsp70-2 results in failed meiosis, germ cell apoptosis, and male infertility. Proc. Natl Acad. Sci. USA 93, 3264-3268.

Dolci, S., Pellegrini, M., Di Agostino, S., Geremia, R., Rossi, P., 2001. Signaling through extracellular signal regulated kinase is required for spermatogonial proliferative response to stem cell factor. J. Biol. Chem. 276, 40225-40233.

Don, J., Wolgemuth, D.J., 1992. Identification and characterization of the regulated pattern of expression of a novel mouse gene, meg1, during the meiotic cell cycle. Cell Growth Differ. 3, 495-505.

Franke, F.E., Kraus, S., Eiermann, C., Pauls, K., Lalani, E.N., Bergmann, M., 2001. MUC1 in normal and impaired spermatogenesis. Mol. Hum. Reprod. 7, 505-512.

Grimaldi, P., Piscitelli, D., Albanesi, C., Blasi, F., Geremia, R., Rossi, P., 1993. Identification of $3^{\prime}, 5^{\prime}$-cyclic adenosine monophosphate-inducible nuclear factors binding to the human urokinase promoter in mouse Sertoli cells. Mol. Endocrinol. 7, 1217-1225.

Ikawa, M., Wada, I., Kominami, K., Watanabe, D., Toshimori, K., Nishimune, Y., Okabe, M., 1997. The putative chaperone calmegin is required for sperm fertility. Nature 387, 607-611.

Kasahara, M., Gutknecht, J., Brew, K., Spurr, N., Goodfellow, P.N., 1989. Cloning and mapping of a testis-specific gene with sequence similarity to a sperm-coating glycoprotein gene. Genomics 5, 527-534.

Kashiwabara, S., Noguchi, J., Zhuang, T., Ohmura, K., Honda, A., Sugiura, S., et al., 2002. Regulation of spermatogenesis by testis-specific, cytoplasmic poly(A) polymerase TPAP. Science 298, 1999-2002.

Kelly, T.E., 1987. Inactivation of the mammalian $\mathrm{X}$ chromosome in spermatogenesis. Am. J. Hum. Genet. 40, 288-289.

Kerr, S.M., Taggart, M.H., Lee, M., Cooke, H.J., 1996. Ott, a mouse Xlinked multigene family expressed specifically during meiosis. Hum. Mol. Genet. 5, 1139-1148.

Kissel, H., Timokhina, I., Hardy, M.P., Rothschild, G., Tajima, Y., Soares, V., et al., 2000. Point mutation in kit receptor tyrosine kinase reveals essential roles for kit signaling in spermatogenesis and oogenesis without affecting other kit responses. Eur. Mol. Biol. Org. J. 19, 1312-1326.

Kohno, N., Yamagata, K., Yamada, S., Kashiwabara, S., Sakai, Y., Baba, T., 1998. Two novel testicular serine proteases, TESP1 and TESP2, are present in the mouse sperm acrosome. Biochem. Biophys. Res. Commun. 245, 658-665.

Kramerova, I.A., Kramerov, A.A., 1999. Mucinoprotein is a universal constituent of stable intercellular bridges in Drosophila melanogaster germ line and somatic cells. Dev. Dyn. 216, 349-360.

Kremling, H., Keime, S., Wilhelm, K., Adham, I.M., Hameister, H., Engel, W., 1991. Mouse proacrosin gene: nucleotide sequence, diploid expression, and chromosomal localization. Genomics 11, 828-834.

Larsson, M., Norrander, J., Graslund, S., Brundell, E., Linck, R., Stahl, S., Hoog, C., 2000. The spatial and temporal expression of Tekt1, a mouse tektin $\mathrm{C}$ homologue, during spermatogenesis suggest that it is involved in the development of the sperm tail basal body and axoneme. Eur. J. Cell Biol. 79, 718-725.

Li, S., Zhou, W., Doglio, L., Goldberg, E., 1998. Transgenic mice demonstrate a testis-specific promoter for lactate dehydrogenase, LDHC. J. Biol. Chem. 273, 31191-31194.

Liu, D., Matzuk, M.M., Sung, W.K., Guo, Q., Wang, P., Wolgemuth, D.J., 1998. Cyclin A1 is required for meiosis in the male mouse. Nat. Genet. 20, 377-380.

Martianov, I., Fimia, G.M., Dierich, A., Parvinen, M., Sassone-Corsi, P., Davidson, I., 2001. Late arrest of spermiogenesis and germ cell apoptosis in mice lacking the TBP-like TLF/TRF2 gene. Mol. Cell 7, 509-515.

Narisawa, S., Hecht, N.B., Goldberg, E., Boatright, K.M., Reed, J.C., Millan, J.L., 2002. Testis-specific cytochrome c-null mice produce functional sperm but undergo early testicular atrophy. Mol. Cell. Biol. $22,5554-5562$
O’Dowd, B.F., Nguyen, T., Lynch, K.R., Kolakowski, L.F. Jr., Thompson, M., Cheng, R., et al., 1996. A novel gene codes for a putative G proteincoupled receptor with an abundant expression in brain. Fed. Eur. Biochem. Soc. Lett. 394, 325-329.

Orlando, P., Geremia, R., Frusciante, C., Grippo, P., 1989. Replicating premeiotic germ cells of the mouse contain a novel DNA primase stimulatory factor. Cell. Differ. Dev. 27, 129-136.

Oulad-Abdelghani, M., Bouillet, P., Decimo, D., Gansmuller, A., Heyberger, S., Dolle, P., et al., 1996. Characterization of a premeiotic germ cell-specific cytoplasmic protein encoded by Stra8, a novel retinoic acid-responsive gene. J. Cell Biol. 135, 469-477.

Pellegrini, M., Grimaldi, P., Rossi, P., Geremia, R., Dolci, S., 2003. Developmental expression of BMP4/ALK3/SMAD5 signaling pathway in the mouse testis: a potential role of BMP4 in spermatogonia differentiation. J. Cell Sci. 116, 3363-3372.

Roeder, G.S., 1997. Meiotic chromosomes: it takes two to tango. Genes Dev. 11, 2600-2621.

Rossi, P., Dolci, S., Albanesi, C., Grimaldi, P., Ricca, R., Geremia, R., 1993. FSH induction of steel factor (SLF) mRNA in mouse Sertolí cells and stimulation of DNA synthesis in spermatogonía by soluble SLF. Dev. Biol. 155, 68-74.

Schena, M., 1996. Genome analysis with gene expression microarrays. Bioessays 18, 427-431.

Schrans-Stassen, B.H., van de Kant, H.J., de Rooij, D.G., van Pelt, A.M., 1999. Differential expression of c-kit in mouse undifferentiated and differentiating type A spermatogonia. Endocrinology 140, 5894-5900.

Schurmann, A., Koling, S., Jacobs, S., Saftig, P., Krauss, S., Wennemuth, G., et al., 2002. Reduced sperm count and normal fertility in male mice with targeted disruption of the ADP-ribosylation factor-like 4 (Arl4) gene. Mol. Cell. Biol. 22, 2761-2768.

Sette, C., Barchi, M., Bianchini, A., Conti, M., Rossi, P., Geremia, R., 1999. Activation of the mitogen-activated protein kinase Erk1 during meiotic progression of mouse pachytene spermatocytes. J. Biol. Chem. 274, $33571-33579$

Sorrentino, V., Giorgi, M., Geremia, R., Besmer, P., Rossi, P., 1991. Expression of the $c$-kit protooncogene in the murine male germ cells. Oncogene 6, 149-151.

Toscani, A., Mettus, R.V., Coupland, R., Simpkins, H., Litvin, J., Orth, J., et al., 1997. Arrest of spermatogenesis and defective breast development in mice lacking A-myb. Nature 386, 713-717.

Wang, D., Li, Z., Messing, E.M., Wu, G., 2002. Activation of Ras/Erk pathway by a novel MET-interacting protein RanBPM. J. Biol. Chem. 277, 36216-36222.

Wishart, M.J., Dixon, J.E., 2002. The archetype STYX/dead-phosphatase complexes with a spermatid mRNA-binding protein and is essential for normal sperm production. Proc. Natl Acad. Sci. USA 99, 2112-2117.

Yan, W., Samson, M., Jegou, B., Toppari, J., 2000. Bcl-w forms complexes with Bax and Bak, and elevated ratios of Bax/Bcl-w and Bak/Bcl-w correspond to spermatogonial and spermatocyte apoptosis in the testis. Mol. Endocrinol. 14, 682-699.

Yoshinaga, K., Nishikawa, S., Ogawa, M., Hayashi, S., Kunisada, T., Fujimoto, T., Nishikawa, S.-I., 1991. Role of c-kit in mouse spermatogenesis: identification of spermatogonia as a specific site of c-kit expression and function. Development 113, 689-699.

Yoshiura, K., Leysens, N.J., Reiter, R.S., Murray, J.C., 1998. Cloning, characterization, and mapping of the mouse homeobox gene Hmx1. Genomics 50, 61-68.

Yu, Z., Guo, R., Ge, Y., Ma, J., Guan, J., Li, S., et al., 2003. Gene expression profiles in different stages of mouse spermatogenic cells during spermatogenesis. Biol. Reprod. 69, 37-47.

Zindy, F., den Besten, W., Chen, B., Rehg, J.E., Latres, E., Barbacid, M., et al., 2001. Control of spermatogenesis in mice by the cyclin Ddependent kinase inhibitors p18(Ink4c) and p19(Ink4d). Mol. Cell. Biol. 21, 3244-3255. 